\title{
Resistance and the Radical Imagination: A Reflection on the Role of the Critical Criminologist in Social Movements
}

\author{
Laura Naegler ${ }^{1}$
}

Accepted: 19 May 2021 / Published online: 5 June 2021

(c) The Author(s) 2021

\begin{abstract}
At times of global unrest and the emergence of a wide range of protest movements, recent intra-disciplinary criminological debates on the potentials and limits of resistance suggest a paradoxical trend. Critical criminologists - in particular, those associated with the ultra-realist perspective-have become increasingly skeptical of the idea of "resistance," itself. In the context of these discussions, scholars have resorted to dismissing oppositional activities-including social movements and their different forms of protest-that are both intended and recognized as resistance. In my contribution to this debate, and in response to Jeff Ferrell's (2019) article, "In Defense of Resistance," I provide a critical reflection on the analysis of social movements in both ultra-realist and cultural criminological scholarship. Drawing from my ethnographic research with the (post-)Occupy movement in the United States, I argue that the dismissive reading of social movements' resistance and the calls for stronger political leadership are the result of a narrow analytical lens applied to movements, their temporalities, and their historical context(s). In addition, I contend that the harsh criticism of social movements by ultra-realists connects to the aim of developing an intellectual leadership concerned with informing social movement practice and strategy "from above." Here, as I maintain, the theory and practice of militant research, or militancia de investigación, as per the Colectivo Situaciones, challenges this understanding of intellectual leadership. The insights provided by radical collective knowledge production in social movements, and their critique of the institutional frameworks of the neoliberal university, allow for a critical reflection on the role of academia in resistance. This critical reflection can generate possibilities for social movements' knowledge and radical imaginations to influence academic theorizing.
\end{abstract}

\section{Introduction}

Resistance has always been central to the critical criminological project, both as an analytical category and as a political imperative. After all, the critical criminology of the last fifty years emerged in resistance to the positivist ideologies of orthodox criminology, which have always been close to power in their attempts to legitimize the harm caused by the

Laura Naegler

Laura.Naegler@liverpool.ac.uk

1 University of Liverpool, Liverpool, United Kingdom 
criminal justice system. A critical criminology that is, at its core, concerned with hegemonic power, then, necessitates attention to how this power is opposed. Indeed, "resistance," as a concept and practice, is fundamentally transgressive-crossing the threshold between what is legal and illegal—or culturally and socially (un)accepted—within the current dominant order. Yet, as Ferrell writes in his article, "In Defense of Resistance," there currently appears to be a paradoxical trend in critical criminology: at times of global political unrest, critical criminologists are increasingly skeptical of the idea of resistance itself.

Much of this trend-and the discussion on the potentials and limits of resistance that accompanies it - can be situated into an intra-disciplinary debate between cultural criminology and its ultra-realist critics. On one side of this debate, there is a strongly anarchist-inspired cultural criminological tradition, which stresses the potentials of everyday, immediate and symbolic acts of defiance and resistance to contemporary capitalism (Brisman 2010; Ferrell 1993/1996, 1994, 1998; Ferrell et al. 2015; Ilan 2019; Lyng 2005; Naegler 2012, 2014), which its critics (e.g., Hall and Winlow 2015) view as being at risk of trailing into a naïve political romanticism. On the other side, ultra-realists reject "cultural micro-resistance" (Hall and Winlow 2007: 84), which they perceive as widely apolitical, pre-emptively incorporated into consumer paradigms (Raymen 2018), and symptomatic of the lack of political imagination paramount in liberal Western democracies (Winlow et al. 2015). Thus, ultra-realists call for a return to "genuine," organized or institutionalized political resistance and leadership (Winlow et al. 2015: 84) which, in turn, raises the suspicion of an intellectual avant-gardism that is, in itself, authoritative and elitist (Ferrell 2007, 2019). While these positions may represent different sides of the spectrum, they are not the only critical criminological perspectives on resistance. For example, Hayward and Schuilenburg (2014), key cultural criminologists, have nonetheless attempted to provide more theoretical clarity to the subject, echoing the ultra-realist concern about assigning the label of resistance too readily to a plethora of often contradictory social practices.

The debate appears, Ferrell points out, as often unnecessarily polarized. At times, it is focused too heavily on either defending or fighting clichés of "rebellious posturing"-be it the middle-class, hipster-activist in her Che-T-shirt more committed to conspicuous consumption than real social change (Ferrell 2019: 8) or the adventure-seeking, risk-taking edgeworker writing graffiti or trespassing in urban contexts, unphased by authority and seemingly invincible to any consequences of his doing, yet alone suffering fatigue or resignation (Naegler and Salman 2016). Here, the ultra-realist skepticism of the resistant intent and effectiveness of these clichés has, in fact, allowed for shifting the focus toward the more politically charged oppositional activities that can be found in "lifestyle politics"1 and organized movements. Questioning the role of intentionality and recognition in resistance-and what constitutes the limits to resist within the system-are important for achieving an understanding of how resistance, and the power it targets, work. In counteracting the tendency to see resistance "everywhere" that came with the cultural turn in critical criminology, however, both ultra-realists and those cultural criminologists who seem to align more with the ultra-realist perspective (e.g., Hayward 2016; Hayward and Schuilenburg 2014) have gone too far, resulting in an "all-or-nothing" dynamic in the debate, denying anything except a full-blown revolution the label of "real" political resistance. Here, the dominant voices in this debate have increasingly resorted to dismissing oppositional

\footnotetext{
1 "Lifestyle politics" refers to the politicization of everyday life choices, where individuals' personal behaviors and their everyday decisions are (seen as) sites of political expression. Such acts are understood as prefiguring a future social and political ideal in the present (Portwood-Stacer 2013).
} 
activities - including social movements and their protest(s) - that are both intended and recognized as resistance. In addition, the debate appears to be motivated by a political aim-a shift of popular struggle "from the streets" toward the establishment of an intellectual leadership in which critical scholars take on the role of contemplating political strategy for social movements.

In my contribution to this debate - and in response to the arguments raised by FerrellI provide a critical reflection on the analysis of the Occupy Wall Street (OWS) movement of 2011-12 by both cultural criminologists and ultra-realists. Drawing from my own research with the (post-)Occupy movement in New York City (Naegler 2018, 2019), I argue that the accounts by ultra-realists and some cultural criminologists (e.g., Hayward 2016; Hayward and Schuilenburg 2014) tend to apply a narrow analytical lens at the expense of in-depth empirical engagement with these social movements. This narrow analytical lens results in a dismissive reading of social movement practice, knowledge production, and their role in collective struggle. Such harsh criticism of social movements, I contend, ties in directly not only with calls for stronger political leadership, but for intellectual leadership concerned with informing social movement practice "from above." This aim to build intellectual leadership comes with its own problems and limitations. But, as I argue below, the debates surrounding resistance-including Ferrell's call for critical criminologists to defend resistance-raise a deeper underlying question: what is the role of academia in resistance? In other words, the question is whether we, as critical criminologists, are really the ones who have to defend resistance - and if there really is a need for us to do so beyond simply defending our own legitimacy within collective struggles.

\section{Moments or Movements?}

In their analysis of the "post-crisis movements," ${ }^{2}$ Winlow and colleagues (2015) criticize OWS as symptomatic of the wider impotence of the contemporary left in Western liberal democracies. Winlow and colleagues (2015) do not deny its revolutionary potential or the problems of the " $99 \%$ vs. the $1 \%$ " dynamic. But instead of living up to its promise, they argue, OWS remained a reactive force rather than one attempting to create a new set of conditions and relationships. As Winlow and colleagues (2015) contend, OWS failed to utilize the force of its criticism of the capitalist elites to craft a coherent realistic political and economic alternative. Part of the reason for this failure stemmed from the movement's insistence on a political "horizontalism" (Sitrin 2012), leading to the absence of a charismatic and inspiring political leader "capable of establishing herself as a just authority figure in the eyes of the disengaged consuming public" (Winlow et al. 2015: 154). In order to be successful, Winlow and colleagues (2015) maintain, the movement should have established political leadership, created a political universalism by refusing to engage with divisive identity politics, and put its focus on building feasible socio-economic alternatives. This would have allowed the wider audience of "de-politicized consumers" in Western liberal democracies to connect their individual grievances with the collective class struggle for economic equality.

\footnotetext{
2 "Post-crisis movements" refers to social movements that emerged in response to the global financial crisis of 2007-2009 (Naegler 2019).
} 
Instead, OWS remained stuck in the spectacle of the moment. The global visibility of the occupation allowed for "raising awareness," but, according to Winlow and colleagues (2015: 153), it did little more, as activists eventually eschewed the "hard work of organizing" within communities, which must follow the immediacy of the spectacle. A strong focus on political organizing would have helped to engage working-class people beyond the (presumably middle-class) protestors in Zuccotti Park. As Žižek (2008, 2010) reminds us, political and social awareness, by itself and in absence of alternatives, can result in cynicism and resignation instead of political participation (Žižek 2008, 2010). As such, in its inability to move "beyond vague abstractions" (Winlow et al. 2015: 4), OWS eventually disappeared from global headlines and "disintegrated" (Winlow et al. 2015: 168) into obsolescence.

Hayward and Schuilenburg (2014), arguing from "within" cultural criminology, provide an analysis of the "post-crisis movements" that overlaps with the ultra-realists' criticisms, mentioned above. Hayward and Schuilenburg's (2014) account, however, is aimed more explicitly toward providing a conceptualization of resistance that counteracts the lack of theoretical clarity of the idea in cultural criminology. Accordingly, they suggest a threestage model of resistance. The initial stage of invention leads to the emergence of resistance forms such as "rebellious posturing" (Hayward and Schuilenburg 2014: 32) and the growth of an anti-authoritarian counterculture. Here, the authors refer exclusively to the cultural resistance of the new left in the United States (US) in the 1960s, leaving unaddressed the question how and why "invention" occurs in the first place-or why it happens only in the realm of culture and lifestyle, and not out of people's experiences of oppression, or the need for survival. The second stage is imitation, in which invented resistance (the first stage) becomes adopted by the wider public, imitated by consumer culture, and eventually "normalized" as a signifier of "resistance lifestyles" (Hayward and Schuilenburg 2014: 33) and identity politics. The last stage, transformation, is the "radical transformation associated with revolution" (Hayward and Schuilenburg 2014: 30)—forceful enough to make a fundamental break with the prevailing order and to disrupt existing relations of power in order to create new political situations.

Based on this three-stage model, Hayward and Schuilenburg (2014) argue that the OWS movement remained stuck in the phases of invention and imitation-in the realm of culture, identity and lifestyle - and that it failed to reach the third, most significant, stagethat of transformation. Rather than being innovative, the OWS movement merely imitated previous movements - an argument that Hayward and Schuilenburg make (2014: 33) based on their observation that some of the banners during OWS used "recycled" slogans from previous alter-globalization protests in the US. The movement also failed to engage in what can be considered truly transformative political resistance due to its fragmented "on the ground" politics and, to make this point, the authors cite a single study on Occupy London (Sotirakopoulos and Rootes 2014), which showed that activists identified with a broad range of leftist political perspectives. For Hayward and Schuilenburg (2014), this study provides enough evidence to conclude that the global Occupy movement failed to articulate and communicate clearly a political strategy beyond mere rebellious symbolism. As a result, it eventually "spiraled into irrelevance" (Hayward and Schuilenburg 2014: 28).

What is striking in their analysis of the broader Occupy movements is how both Hayward and Schuilenburg's (2014) stage model and Winlow and colleagues' (2015) advocacy of vertical structures and leadership in collective struggles dismisses OWS as a momentlittle more than a fleeting outburst of discontent that disappeared as quickly as it emerged and remained politically insignificant precisely due to this immediacy. Removed from its historical context, this "movement-moment," so to speak, is then, somewhat paradoxically, 
blamed for its lack of consequence. Hayward and Schuilenburg's (2014) criticism that the Occupy movement was not "inventing," but merely "imitating" and thus not engaging in "real" resistance, for example, is relevant only when one assumes the movement happened in an historical vacuum. At least in the US, OWS never claimed to invent something completely new: it consciously imitated the politics established by radical movements of the Global South in creating forms of direct political participation (Sitrin 2012; Sitrin and Azzellini 2014). And, after all, the question remains how any relevant social movement could ever act or exist without its historical predecessors-yet alone, why this state of autonomy could be considered politically desirable.

Spontaneous protests that attract a critical mass are often characterized by a convergence of vertical and horizontal organizing structures, which can impact the trajectories of popular movements beyond a particular critical moment. For the activists who initiated OWS in Zuccotti Park in the center of the Financial District in Lower Manhattan in New York City, the success of the occupation came as a surprise: many had their doubts that it would last longer than twenty-four hours before the police would evict the protestors. Because of long-established networks, however, the OWS activists were able to deal with the challenges they soon faced-ranging from outreach and media work to the everyday logistics of the encampments. Rather than failing to offer constructive solutions, OWS and its anarchist-inspired politics were centrally about creating and experiencing alternatives to the status quo (Naegler 2018, 2019). In other words, the prefigurative politics of OWS were based on the belief that any desired future structures and social relationships must be created in the present (Springer 2014) as a precondition to any macro-level transformation.

The activists engaged in these prefigurative politics aimed to eventually overcome the totality of current conditions and dominant power-by actively seeking "alternatives that provide a point of alterity or exteriority that calls the limits of the existing order into question" (Springer 2014: 3) through which a different world might emerge that otherwise could not be imagined. Creating these alternatives also aims to demonstrate that this point of exteriority to dominant power already exists in the present, making overcoming its totality possible (Naegler 2018). Accordingly, the structures and direct democratic organizing practices established during OWS served a purpose beyond the provision of basic needs. They were expressions of the broader movement's desire to create egalitarian alternatives to the status quo-with the hope that these would eventually exceed the confines of Zuccotti Park. In this understanding, the radical imagining of a different world is fundamentally a collective practice that comes to existence through people's immediate experiences of autonomy and alternatives (Haiven and Khasnabish 2014). This radical imagination, as the late David Graeber (2009) points out, is both a productive capacity, or the material process of bringing visions into being, and a process of sympathetic identification. It includes imagination as the ability to adopt another person's point of view that is central to create and maintain social relationships (Graeber 2009). It is through this imagination that networks of affinity and solidarity (Clough 2012) are created, whose existence are a fundamental necessity for successful long-term organizing.

These prefigurative politics continued in the "hard work of organizing," which, despite Winlow and colleagues' (2015) claim, took place in less spectacular ways than the occupations. As Harvey $(2012: 119,161)$ points out in his analysis of OWS, it was the movement's distinctly "urban manifestation" and its display of the "collective power of bodies in public space" which held its potential for anti-capitalist struggle. "The city," Harvey (2012: 131) contends, as one of the prime sites of capitalist accumulation, is produced by the labor of thousands of workers; their central role in this process indicates their capacity to disrupt the circles of capital at their core and to hit the "wealthy 
classes" where they are "the most vulnerable ... in terms of the value of the assets they control." The broader Occupy movement revealed the effectiveness of disrupting urban economies because it generated the potential for the "unorganized urbanization producers" to explore their revolutionary capacities, turning the question, "how does one organize a city?" (Harvey 2012: 135), into one of the key issues for the anti-capitalist struggle.

Following this idea of "organizing the city," post-Occupy activists decided on a strategic move that entailed shifting from occupying public spaces to reclaiming private property and fighting gentrification and housing inequality. By doing so, they formulated both a critique of the dominant ideology of private property and an understanding of its class and race dimensions. Starting in 2012, activists involved in the various Occupy movements joined with preexisting anti-foreclosure organizations in cities such as Atlanta, Boston, Chicago, Detroit, and Minneapolis (Naegler 2019). These "Occupy Homes" coalitions that emerged were reacting to the devastating impact of the housing crisis of 2007 to 2009 by fighting evictions and foreclosures in targeted on-the-ground campaigns, blockades, and protests. As a decentralized association that involved homeowners, community organizers and activist groups, Occupy Homes did not simply expose economic injustice, but soon achieved successes by effectively preventing evictions and foreclosures (Gottesdiener 2012). In New York City and San Francisco, post-Occupy activist networks fought gentrification by developing practical strategies to deal with the direct material consequences of rising rents and evictions through the creation of structures of mutual aid in the community (Naegler 2018, 2019). These efforts also included challenging the argument that gentrification is "natural" and exposing how individual suffering is connected to economic and political structures, and that fighting both requires collective solutions.

This also meant connecting the fight against gentrification with a political economy in which racism serves a functional purpose, both historically and structurally, in capitalist modes of production and exploitation. Displacement and homelessness, given the race and class dimensions inherent in gentrification, predominantly affect working-class and poor Black people and people of color (Lees 2016); gentrification often leads to increased police violence against and surveillance of ethnic communities in order to create so-called "safe spaces" (Maharawal 2017; Smith 1996). It was precisely this connection between the racialized political economy of gentrification and police violence that was also addressed by the Black Lives Matter (BLM) movement that emerged in the US in 2014: here, BLM activists have made explicit how policing strategies protect capitalist urban restructuring (Maharawal 2017; Taylor 2016). Rather than transcending the "debilitating logic of identity politics" (Winlow et al. 2015: 152), activists, here, emphasize-and build their organizing around - the understanding that connecting personal grievances with a critique of the political economy requires putting race politics at the center of analysis.

Finally, it is important to point out that OWS did not simply "disintegrate" (Winlow et al. 2015: 168). Nor did the broader Occupy movement merely "spiral into irrelevance" (Hayward and Schuilenburg 2014: 28). The encampments in Zuccotti Park were destroyed by massive police force, by the violent raids on the encampments, and by the mass arrests and continuous surveillance of activists. Moments of confrontation-when an act is recognized as resistance and reacted to by authorities - reveal much about how power works (Naegler 2019). The aggressive reaction by authorities to social movements might, in itself, indicate that there is something about them that matters- that they have been successful in revealing the vulnerabilities of those in power and have tapped into the resistant potential of collective disruption. 


\section{The Limits of Intellectual Leadership}

In his response to the ultra-realist criticism of resistance, Ferrell (2019) points to the absence of practical experiences in activism within the debate, wondering if the skepticism of those dismissing resistance stems from their lack of actively engaging in it. The implication is that the critical academic must, to a certain extent, be a researcher-activist if his/her/ their commitment to social change is to be taken seriously. While this perspective can be problematic because it assumes that we all have the same resources to do so, it does raise a profound question: what is the role of the critical academic in resistance? When one considers the ultra-realists, it seems less that they are not engaged in "activism"; rather, ultrarealists seem to understand activism as fundamentally different from Ferrell's anarchist everyday resistance. The ultra-realists' appeals are also calls to redefine political leadership as a form of intellectual leadership. Here, it becomes the role of the "critical intellectual" and his/her/their radical analysis to inform movement practice-by creating alternative political and socio-economic frameworks, which might inspire and lead the energy and emotion on "the streets" (Winlow et al. 2015: 203) into a robust popular movement. As Ferrell (2019: 7), points out, this intellectual avant-gardism is at risk of being perceived as elitist by favoring the establishment of a hierarchy of knowledge in defining resistance. But it also fundamentally disregards the limits and limitations of academic knowledge production, and it assumes a unidirectional flow of information and knowledge, ignoring the possibilities of social movements' knowledge influencing academic theorizing. This includes the necessary critique on the limits of developing counter-hegemonic ideas within the institutional frameworks of the neoliberal university (Tombs and Whyte 2019).

The Argentinian research collective, Colectivo Situaciones (CS), has been central in developing the practice of militancia de investigacion-militant research that informed the Occupy movement (Bookchin et al. 2013) and that allows for radical collective knowledge production within social movements. In developing this practice, the researcher-activists of the CS have also provided a detailed critique of what they consider the limits of academic research. Academic research, as they point out, is inevitably tied to the frameworks and demands of the academic institution, to which the researcher must capitulate (Colectivo Situaciones 2003). Within these frameworks, even the most "critical" research is subsumed under the paradigms of market efficiency and scientific objectivity that reify those under scrutiny. Academic researchers, constructing "research subjects" to be analyzed under their "objective" gazes, are often not required to investigate their own role in the research process, as the necessary consistency of "objective" knowledge can be produced only because the researcher is positioned "outside" of the field (Holdren and Touza 2005). The more academic research uses these "objectifying powers" (Colectivo Situaciones 2003: 189), the more effective and "valuable" it can present itself to be in the realm of the market and social scientific discourse. This eventually manifests in the disregard for and devaluation of other forms of non-academic and subaltern knowledge, including the knowledge produced by social movements themselves (Colectivo Situaciones 2003).

Many of this cautioning about the fetishization of scientific objectivity and its impact on knowledge production is echoed in the criticism voiced by both cultural criminologists (Ferrell and Hamm 1998; Young 2011) and ultra-realists (Winlow and Hall 2012). The conclusions drawn by the militant researchers of the CS, however, are far more uncompromising. For them, militant research — or radical collective knowledge production and the activism that takes the form of its production - can, by definition, never realize itself within the institutional frameworks of the university. In academia, the objectification of those under scrutiny and the 
surrendering to demands of marketization of knowledge production is inevitably inherent in any institutionalized research process (Colectivo Situaciones 2003). Neither politically radical and critical academic research, nor the advocacy research intended to "give voice" to those not holding the means to make themselves "heard" (Ross, 2013), is exempt from this. This kind of academic research can never be truly radical research. Echoing the principles of prefiguration, which insist that radical transformative change can be achieved only when hegemonic power is, even if just momentarily, made obsolete (Naegler 2018), militant research can occur only outside, or irrespective of, the university (Russell 2015). Understood as the collective tool to achieve reflection, enable decision-making, and allow for critical knowledge production within social movements (Juris 2007), militant research is constituted by its commitment to popular struggle. It can neither exist apart from this commitment, nor with the demands of the university (Russell 2015).

This understanding of radical knowledge production within social movements and outside the university does not imply that our attempts as critical academics are obsolete. Militant research, as its proponents emphasize (Colectivo Situaciones 2003; Juris 2007; Ross 2013), can co-exist with academic research, and academics can contribute meaningfully to a social movement's collective knowledge production. The radicalism inherent in this idea, however, can serve as a useful reminder that the university is not, per se, a place in which radicalism and dissent can flourish unimpacted by wider structures of power and domination. As Tombs and Whyte (2019) point out, the university takes on a paradoxical role. It is simultaneously a place for the development of counter-hegemonic ideas and a place for the reproduction of hegemonic power and "capitalist domination" through the very kind of hegemonic "common sense construction and manipulation" that serves those in power (Tombs and Whyte 2019: 50). Academics tend to overestimate their own autonomy within the context of the university - and, with this, one might add, their own importance in collective struggles. Realistically, critical academics' resistant potential is limited in its impact on hegemonic power by the very political and economic demands that the institution imposes on them.

In the "scholarly utopian blueprint "from above"" (Greener et al. 2019: 15) suggested by ultra-realists and some cultural criminologists (e.g., Hayward 2016; Hayward and Schuilenburg 2014), what is eventually neglected is that the creation of subversive knowledge is a cooperative practice that evolves from dialectically integrating theory and practice within collective struggles (Tombs and Whyte 2019). Giving critical scholars the role of leading the design of political strategy can happen only at the expense of this cross-fertilization of knowledge that emerges within "organic" relationships (Gramsci 1971) between radical academics and social movements. Academic critical analysis and the debates taking place in academic journals or conferences are hardly accessible to the wider public: it remains difficult to see how, in practice, this can form the basis of any intellectual leadership. But radical academic work is at its strongest when joined with the resistance that happens outside of the university and within popular movements (Tombs and Whyte 2019). In this moment of convergence, social movements' radical knowledge production can become a corrective of our own political practice, putting into perspective the many ways in which our own radical imagination is held captive within institutional frameworks. 


\section{Conclusion}

Winlow and colleagues (2015) are right in emphasizing that a fundamental necessity of successful resistance lies in the creation of alternatives and the emergence of a radical imagination that transcends the status quo. They are also correct in pointing out the importance of long-term organizing: resistance that involves organizing-a solidification of social relations with ideological coherence and counter-hegemonic power-is one of its most powerful forms. But this does not mean that mobilization, or immediate acts of resistance, are futile because they can provide the basis for building movements and creating networks of solidarity, as was the case for the broader Occupy movement and OWS, in particular. The dismissal of the broader Occupy movement as a moment devoid of encouraging consequences and "positive utopian thinking" in the ultra-realist (and some cultural criminological (Hayward 2016; Hayward and Schuilenburg 2014)) accounts neglect these complexities of organizing and mobilizing. It also ignores the theoretical and political work aimed at achieving a radical imagination strong enough to create action, instead of merely reaction, that has been, and is continually, undertaken within social movements.

Here, Winlow and colleagues (2015) and Hayward and Schuilenburg's (2014) solution to what they perceive as the failure of leftist movements consists predominantly of the abandonment of identity politics and the establishment of an intellectual leadership (Greener et al. 2019). On a practical level, however, it is difficult to imagine that any popular movement could succeed if it tells people their own reality of oppression is simply a footnote in history that can be dealt with once the "real problems" have been solved. The strength of prefigurative politics, such as those of OWS and the broader Occupy movement, is that they are built upon the belief that if we cannot materialize the outlines of transformative change in the present, we will not succeed to do so in future. The difficult task of achieving social change cannot be done in the abstract: it is a collective task, it must happen on the ground, and it is here where utopian visions are put to the test.

As critical criminologists, we need to be honest: the revolution will not be won in academic journals. The assumption that we can take on a position of intellectual leadership ignores the fact that our forms of academic knowledge production and our own radical imagination are limited—and, with this, eventually our role in resistance and developing social movements. When it comes to the question of our role as critical criminologists in resistance, we should be continuing to assist-not lead - the development of critical forms of knowledge that are emergent from social movements. But we are not the ones who need to defend the resistance of social movements because their resistance will continue to exist irrespective of what we want it to be (or whether we characterize it as "resistance"). Moreover, because we have not even figured out a way to resist inequality in our own institutions, including the fact that our critical criminological project is still predominantly Anglo-centric, White and male-dominated (Chesney-Lind and Chagnon 2016; Naegler and Salman 2016), maybe instead of reifying the debates on which social movement was a success and which one a failure, and defending our own legitimacy in the process, we should take a step back. We should look at how our forms of academic knowledge production reproduce inequality and adherence to the demands of a neoliberal institution, and at the very kind of intellectual leadership they currently prefigure. And maybe we should start resisting there and then. 
Open Access This article is licensed under a Creative Commons Attribution 4.0 International License, which permits use, sharing, adaptation, distribution and reproduction in any medium or format, as long as you give appropriate credit to the original author(s) and the source, provide a link to the Creative Commons licence, and indicate if changes were made. The images or other third party material in this article are included in the article's Creative Commons licence, unless indicated otherwise in a credit line to the material. If material is not included in the article's Creative Commons licence and your intended use is not permitted by statutory regulation or exceeds the permitted use, you will need to obtain permission directly from the copyright holder. To view a copy of this licence, visit http://creativecommons.org/licenses/by/4.0/.

\section{References}

Bookchin, N., Brown, P., Ebrahimian, S., colectivo Enmedio, Juhasz, A., Martin, L., MLT, Mirzoeff, N., Ross, A., Saab, A.J. \& Sitrin, M. (2013). Militant Research Handbook. New York: Steinhardt School of Culture, Education, and Human Development, New York University. Retrieved on June 1, 2021, from http://www.visualculturenow.org/wp-content/uploads/2013/09/MRH_Web.pdf.

Brisman, A. (2010). 'Creative crime' and the phytological analogy. Crime Media Culture, 6(2), 205-225.

Chesney-Lind, M., \& Chagnon, N. (2016). Criminology, Gender and Race: A Case Study of Privilege in the Academy. Feminist Criminology, 11(4), 311-333.

Clough, N. (2012). Emotion at the Center of Radical Politics. On the Affective Structures of Rebellion and Control. Antipode, 44(5), 1667-1686.

Colectivo Situaciones. (2003). On the Researcher-Militant. Sebastian Touza, trans. Retrieved on April 28, 20201, from http://cril.mitotedigital.org/sites/default/files/content/colectivo_situaciones_researcher_ militant.pdf.

Ferrell, J. (1994). Confronting the Agenda of Authority: Critical Criminology, Anarchism, and Urban Graffiti. In G. Barak (Ed.), Varieties of criminology: Readings from a dynamic discipline (pp. 161-178). Westport, CT: Praeger.

Ferrell, J. (1993/1996). Crimes of style: Urban graffiti and the politics of criminality. Boston, MA: Northeastern University Press.

Ferrell, J. (1998). Against the Law: Anarchist Criminology. Social Anarchism, 25. Retrieved on March 24, 2021, from http://library.nothingness.org/articles/SI/en/display/127.

Ferrell, J. (2007). For a ruthless cultural criticism of everything existing. Crime Media Culture, 3(1), 91-100.

Ferrell, J. (2019). In Defense of Resistance. Critical Criminology: An International Journal, https://doi.org/ 10.1007/s10612-019-09456-6.

Ferrell, J. \& Hamm, M. (1998). True Confessions: Crime, Deviance, and Field Research. In J. Ferrell \& M. Hamm (Eds.), Ethnography at the Edge: Crime, deviance, and field research (pp. 2-19). Boston, MA: Northeastern University Press.

Ferrell, J., Hayward, K. \& Young, J. (2015). Cultural Criminology. An Invitation. ${ }^{\text {nd }}$ Edition. Los Angeles, CA: Sage.

Gottesdiener, L. (2012). We win when we live here: occupying homes in Detroit and beyond. Waging Nonviolence, March 28. Retrieved on March 24, 2021, from http://wagingnonviolence.org/feature/we-winwhen-we-live-here-occupying-homes-in-detroit-and-beyond/?pf=true.

Graeber, D. (2009). Direct Action: An Ethnography. Oakland, CA: AK Press.

Gramsci, A. (1971). Selections from the Prison Notebooks. Translated by Q. Hoare and G. Nowell-Smith. London: Lawrence \& Wishart.

Greener, J., Hart, E. L. \& Moth, R. (2019). Resisting the Punitive State-Corporate Nexus: Activist Strategy and the Integrative Transitional Approach. In E. L. Hart, J. Greener \& R. Moth (Eds.), Resist the Punitive State: Grassroots Struggles Across Welfare, Housing, Education and Prison (p. 3-27). London: Pluto Press.

Haiven, M. \& Khasnabish, A. (2014). The Radical imagination: Social movement research in the age of austerity. London: Zed Books.

Hall, S. \& Winlow, S. (2007). Cultural criminology and primitive accumulation. Crime Media Culture,3(1), 82-90.

Hall, S. \& Winlow, S. (2015). Revitalizing criminological theory: Towards a new ultra-realism. London: Routledge.

Harvey, D. (2012). Rebel cities: From the right to the city to the urban revolution. London: Verso. 
Hayward, K. \& Schuilenburg, M. (2014). To resist = To create? Some thoughts on the concept of resistance in cultural crimninology. Cultuur \& Criminaliteit, 4(1), 22-36.

Hayward, K. (2016). Cultural criminology: Script rewrites. Theoretical Criminology, 20(3), 297-321.

Holdren, N. \& Touza, S. (2005). Introduction to Colectivo Situaciones. ephemera, 5(4), 595-601.

Ilan, J. (2019). Cultural Criminology: The Time is Now. Critical Criminology: An International Journal, 27(1), 5-20. https://doi.org/10.1007/s10612-019-09430-2.

Juris, J. (2007). Practicing Militant Ethnography with the Movement for Global Resistance in Barcelona. In S. Shukaitis, D. Graeber, \& E. Biddle (Eds.), Constituent imagination. Militant investigations, collective theorization (pp.164-176). Oakland, CA: AK Press.

Lees, L. (2016). Gentrification, Race, and Ethnicity: Towards a Global Research Agenda? City \& Community, 15(3), 208-214.

Lyng, S. (2005). Edgework and the Risk-Taking Experience. In S. Lyng (Ed.), Edgework: The sociology of risk-taking (pp. 3-14). New York and Abingdon, Oxon, UK: Routledge.

Maharawal, M. (2017). Black Lives Matter, gentrification and the security state in the San Francisco Bay Area. Anthropological Theory, 17(3) 338-364.

Naegler, L. (2012). Gentrification and Resistance: Cultural criminology, control, and the commodification of urban protest in Hamburg. Hamburg: LIT-Verlag.

Naegler, L. (2014). The Ritual of Insurrection and the 'Thrill-Seeking Youth': An Instant Ethnography of Inner-City Riots in Germany. In D. Pritchard \& F. Pakes (Eds.), Riot, unrest and protest on the global stage (pp.151-168). Basingstoke, Hampshire, UK: Palgrave Macmillan.

Naegler, L. (2018). 'Goldman-Sachs Doesn't Care If You Raise chicken': The challenges of resistant prefiguration. Social Movement Studies, 17(5), 507-523. https://doi.org/10.1080/14742837.2018.1495074.

Naegler, L. (2019). Prefigurative Politics as Resistance to State-Corporate Harm. Fighting Gentrification in post-Occupy New York City. In E. L. Hart, J. Greener \& R. Moth (Eds.), Resist the Punitive State. Grassroots Struggles Across Welfare, Housing, Education and Prison (p. 28-45). London: Pluto Press

Naegler, L. \& Salman, S. (2016). Cultural Criminology and Gender Consciousness. Moving Feminist Theory From Margin to Center. Feminist Criminology, 11(4), 354-374.

Portwood-Stacer, L. (2013). Lifestyle Politics and Radical Activism. London: Bloomsbury Publishing.

Raymen, T. (2018). Parkour, deviance and leisure in the late-capitalist city. London: Emerald.

Ross, A. (2013). Research for Whom? In N. Bookchin, P. Brown, S. Ebrahimian, colectivo Enmedio, A. Juhasz, L. Martin, MLT, N. Mirzoeff, A. Ross, A. J. Saab \& M. Sitrin (Eds.), Militant Research Handbook (pp. 8-10). New York: Steinhardt School of Culture, Education, and Human Development, New York University. Retrieved on June 1, 2021, from http://www.visualculturenow.org/wp-content/uploa ds/2013/09/MRH_Web.pdf.

Russell, B. (2015). Beyond activism/academia. Militant research and the radical climate and climate justice movement(s). Area, 47(3), 222-229.

Sitrin, M. (2012). Everyday Revolutions: Horizontalism and Autonomy in Argentina. London: Zed Books.

Sitrin, M. \& Azzellini, D. (2014). They can't represent us! Reinventing democracy from Greece to Occupy. London: Verso.

Smith, N. (1996). The new urban frontier: gentrification and the revanchist city. London: Routledge.

Sotirakopoulos, N. \& Rootes, C. (2014). Occupy London in international and local context. In D. Della Porta \& A. Mattoni (Eds.), Spreading Protest: Social Movements in Times of Crisis (pp. 171-192). Colchester, UK: ECPR Press.

Springer, S. (2014). Space, Time and the Politics of Immanence. Global Discourse, 4(2-3), 159-162.

Taylor, K.-Y. (2016). From \#blacklivesmatter to Black Liberation. Chicago, IL: Haymarket Books.

Tombs, S. \& Whyte, D. (2019). Struggles Inside and Outside the University. In E. L. Hart, J. Greener \& R. Moth (Eds.), Resist the Punitive State. Grassroots Struggles Across Welfare, Housing, Education and Prison (p. 46-65). London: Pluto Press

Winlow, S., Hall, S., Treadwell, J. \& Briggs, D. (2015). Riots and political protest: Notes from the postpolitical present. Abingdon, Oxon, UK, and New York: Routledge.

Winlow, S. \& Hall, S. (2012). What is an 'Ethics Committee' Academic Governance in an Epoch of Belief and Incredulity. The British Journal of Criminology, 52(2), 400-416.

Young, J. (2011). The criminological imagination. Cambridge, UK: Polity Press.

Žižek, S. (2008). The sublime object of ideology. New York, London: Verso.

Žižek, S. (2010). Living in the end times. London: Verso.

Publisher's Note Springer Nature remains neutral with regard to jurisdictional claims in published maps and institutional affiliations. 